\title{
[18F ]F luoroethoxy-Benzovesamicol, a PET Radiotracer for the Vesicular Acetylcholine Transporter and Cholinergic Synapses
}

\author{
G. KEITH MULHOLLAND,* DONALD M. WIELAND, MICHAEL R. KILBOURN, KIRK A. FREY, \\ PHILLIP S. SHERMAN, J AMES E. CAREY, AND DAVID E. KUHL \\ Division of Nuclear Medicine, Department of Internal Medicine, University of Michigan Medical Center, \\ 3480 KresgellI, Ann Arbor, Michigan, USA 48109-0552
}

\begin{abstract}
KEY WORDS autoradiography; cholinergic; dosimetry; imaging; PET; synapse; vesamicol
\end{abstract}

\begin{abstract}
Loss of cholinergic transmission in the cortex and hippocampus is a characteristic feature of Alzheimer's disease, and visualization of functional cholinergic synapses in the brain with PET could be a useful method for studying this degenerative condition in living humans. We investigated $\left[{ }^{18} \mathrm{~F}\right]$ fluoroethoxybenzovesamicol, (-)$\left[{ }^{18} \mathrm{~F}\right] \mathrm{FE} \mathrm{OBV},(-)-(2 \mathrm{R}, 3 \mathrm{R})$-trans-2-hydroxy-3-(4-phenyl piperidino)-5-(2-[ $\left.{ }^{18} \mathrm{~F}\right]$ fluoroethoxy)1,2,3,4-tetralin, a high affinity positron emitting ligand for the vesicular acetylcholine transporter, as a potential in vivo chol inergic synapse mapping agent. Rodent biodistribution, dosimetry, stereospecificity of bi ological effects, pharmacologic blocking studies, in vivo rodent brain autoradiography and metabolites were examined. $(-)-\left[{ }^{18} \mathrm{~F}\right] \mathrm{FEOBV}$ brain uptake following intravenous injection was robust, with $2.65 \%$ dose/brain in mice at $5 \mathrm{~min}$, and the regional localization matched the known distributions of presynaptic cholinergic markers at later times. Both the cholinergic localization and curare-like effects of FEOBV were associated with the "(-)"-enantiomer exclusively. (-)$\left[{ }^{18} \mathrm{~F}\right] \mathrm{FE} O \mathrm{BV}$ regional brain distribution in rodents was changed little by pretreatment with haloperidol, (+)-3-PPP, or E-2020, indicating FEOBV, unlike other vesamicol anal ogs, did not interact in vivo with dopamine or $\sigma$ receptor systems. Autoradiography of rat brain $3 \mathrm{~h}$ following i.v. injection of $(-)-\left[{ }^{18} \mathrm{~F}\right] \mathrm{FEOBV}$ showed high localization in brain areas rich in presynaptic cholinergic el ements. Metabolic defluorination in rodents was modest, and analysis of brain tissue fol lowing tracer administration found FEOBV as the only extractable radi oactive species. (-)-[18 F FFEOBV dosimetry calculated from rat data estimate $10 \mathrm{mCi}$ doses can be given to humans. These studies show FEOBV maps cholinergic areas with high specificity in vivo, and may provide a noninvasive means to safely and accurately gauge the functional integrity of cholinergic synapses in man using PET. Synapse 30:263-274, $1998 . \quad \odot 1998$ Wiley-Liss, Inc.
\end{abstract}

\section{INTRODUCTION}

A dramatic loss of acetylcholine (ACh) and its metabolically rel ated enzymes from the cortex and hippocampus is a characteristic feature of Alzheimer's disease (AD) (Perry et al., 1994). In addition, loss of synaptic elements in the cortex and subcortical brain areas is correlated with the severity of cognitive dedine in $A D$ (Davies et al., 1987; DeK osky and Scheff, 1990; Masliah et al., 1992a,b; Samuel et al., 1994; Scheff et al., 1990; Terry et al., 1991). Some studies have found synaptic and neuronal loss to be even more strongly correlated with AD symptoms than the senile plaques and neurofibrillary tangles that are the diagnostic hallmarks of the disease (Gomez-Isla et al., 1997; Masliah et al., 1992b;
Svennerholm and Gottfries, 1994; Terry et al., 1991). The synaptic pathology of AD involves neurons of multiple transmitter types, but loss of cholinergic presynaptic function in the neocortex appears to be a crucial component in the development of visuospatial deficits and impaired working memory that occurs with the disease (Perry et al., 1994). Several current pharma-

Contract grant sponsor: National Institutes of Health; Contract grant numbers: 5 RO1 NS24896, 2 RO1 NS25656, 2 PO1 NS15655, 1P50 HL52323; Contract grant sponsor: Department of Energy; Contrast grant number: DEFG-0287ER60561.

*Correspondence to: G. Keith Mulholland, Ph.D., Indiana University School of Medicine, Department of Radiology, $975 \mathrm{~W}$. Walnut St, I B 028N, Indianapolis, IN 46202-5121. E-mail: kmulholl@xray.indyrad.iupui.edu

Received 7 December 1997; Accepted 30 December 1997 
cologic treatments for $A D$ are aimed at enhancing cholinergic neurotransmission in the brain (Brennan, 1997). The root causes of neurodegeneration in AD are not understood (Itzhaki, 1994), and a definitive diagnosis of disease can be made only after death. The ability to measure cholinergic synapses in the living human brain could be an important investigative tool for assessing neuronal damage, or for monitoring the efficacy of future neuron-sparing therapies for this devastating condition.

For these reasons, considerable efforts have been focused on developing radiotracer imaging techniques to visualize elements of presynaptic cholinergic function. One approach has employed radiolabeled ligands or substrates of acetylcholinesterase (AChE) as markers of cholinergic activity (Irie et al., 1994; Kilbourn et al., 1996; Pappata et al., 1996). Another method, and the basis for the present work, targets the vesicular ACh transporter (VAChT) in cholinergic terminals with radiolabeled forms of the drug vesamicol (Altar and Marien, 1988). VAChT is a glycoprotein located in cholinergic synaptic vesicle membranes which draws cytoplasmic ACh into the vesicles. Vesamicol binds on VAChT to a so-called vesamicol receptor site that is noncompetitive with ACh binding and, therefore, presumably not affected by changes in endogenous ACh levels. VAChT tissue distribution is highly correlated and uniquely distributed with other proteins involved in the presynaptic metabolism of ACh, including choline acetyltransferase (ChAT), high affinity choline uptake protein, and acetylcholinesterase. The close association of VAChT with other cholinergic markers was recognized originally from vesamicol binding studies (Altar and Marien, 1988), and has been confirmed recently using hybridization binding techniques with cloned VAChT gene cDNA probes (E rickson et al., 1994, 1996; Roghani et al., 1994), and VAChT immunochemistry (Gilmor et al., 1996). I t has been discovered that the human VAChT gene lies nestled within the ChAT gene locus and these two genes are co-expressed in a tightly coupled fashion. A mounting body of evidence points to VAChT as being a very specific marker of cholinergic terminals. General recognition of this fact, and the discovery of many potent anal ogs based on the vesamicol template, has spurred the search for suitable radioligands for measuring VAChT in vivo (Efange et al., 1992; Parsons and Rogers, 1993; Efange et al., 1993, 1994, 1995a; J ung et al., 1996; Mach et al., 1997).

We studied a class of analogs called benzovesamicols, discovered by Rogers et al. (1989), and identified a number of novel radiolabeled benzovesamicol analogs which distribute in vivo in patterns that correlate closely with the densities of marker proteins of the cholinergic nerve terminal. Analogs with radioiodine, carbon-11, or fluorine-18 labels at the 5 position of the 2-hydroxy-3-N-(4-phenyl)-piperidino-tetralin framework, which we term 5-substituted-benzovesamicols (other investigators identify the same compounds as 4-benzovesamicols using a different nomenclature; see Parsons and Rogers, 1993) have shown particularly favorable imaging properties (J ung et al., 1990; Kilbourn et al., 1990; Mulholland et al., 1991a, b; I ngvar et al., 1993). Human SPECT (single photon emission computed tomography) imaging studies with the ${ }^{123}$ |labeled benzovesamicol anal og 5-I BVM show decreases in tracer binding in several brain regions of AD patients (Kuhl et al., 1994, 1996). These studies offer encouragement that appropriate benzovesamicol tracers can map cholinergic neurons and gauge the functional integrity of cholinergic synapses in man.

With the aim to extend human benzovesamicol imaging studies to a higher level of precision with positron emission tomography (PET), we developed a novel fluorine-18-labeled agent, 5-fluoroethoxy-benzovesamicol (FEOBV, Fig. 1). The synthesis of [ $\left.{ }^{18} \mathrm{~F}\right] F E O B V$ (Mulholland et al., 1993) and an examination of its kinetics in the perfused rat heart (Degrado et al., 1994) were reported previously. The present communication examines distribution and pharmacologic properties of FEOBV in animals, compares them with those of related agents, and covers evaluation steps of FEOBV preliminary to its introduction as an investigational cholinergic synaptic tracer for human PET imaging studies.

\section{MATERIALS AND METHODS}

$(-)-\left[{ }^{18} \mathrm{~F}\right] \mathrm{FEOBV}$ was labeled in a "one-step" nucleophilic radiofluorination procedure from "no-carrieradded" [18F ]fluoride ion and (-)-(2R,3R)-5-(2-tosyloxyethoxy)-benzovesamicol (Mulholland et al., 1993). The specific activity of the final tracer product at the end of synthesis exceeded $3 \mathrm{Ci} / \mu \mathrm{mol}$ (range 3-17 Ci/ $\mu \mathrm{mol}$, average $8 \mathrm{Ci} / \mu \mathrm{mol}$ ) following HPLC purification, and the radiochemical purity was greater than $99 \%$, as assayed by reverse phase HPLC. The inactive " $(+)$ "enantiomer of FEOBV was label ed by the same route to the same qual ity specifications as (-)-FEOBV, starting from resolved (+)-5-(2-tosyloxyethoxy)-benzovesamicol.

Experiments with living animals were performed in accordance with the United States Department of AgricultureAnimal WelfareAct.

\section{Mouse biodistribution studies}

Female CD-1 mice weighing 23-34 g were anesthetized lightly with diethyl ether and given tail vein injections of 7-600 $\mu \mathrm{Ci}$ of $(-)-\left[{ }^{18} \mathrm{~F}\right] \mathrm{FEOBV}$. Theanimals then resumed normal activity until the times of sacrifice, which ranged from $5 \mathrm{~min}$ to $15 \mathrm{~h}$ postinjection. Mice were killed under ether anesthesia by decapitation and tissues were quickly excised, weighed, and counted for radioactivity in an auto gamma counter. Samples from brains included striatum, whol e cerebral cortex, hippocampus, hypothalamus, and cerebellum. 
The results were corrected for radioactive decay and expressed in terms of percent injected dose per organ (\%dose/organ), percent injected dose per gram of tissue (\%dose/g), normalized to an animal weight of $25 \mathrm{~g}$. Tissue concentration ratios were calculated from tissue pairs for each animal and then averaged together to yield tissue-to-cerebellum ratios. Each data point represented the mean \pm standard deviation of values from at least three animals. Data were analyzed for significance using unpaired two-tailed t-tests.

\section{Pharmacologic pretreatment studies}

Female CD1 mice ( $n=3$ per data point) were given interperitoneal injections of either haloperidol $(10 \mathrm{mg} /$ $\mathrm{kg}),(+)$-3-PPP (20 mg/kg), or E-2020 (donepezil) (10 $\mathrm{mg} / \mathrm{kg}) 30$ to $60 \mathrm{~min}$ prior to $\mathrm{FEOBV}$ radiotracer administration ( $30 \mu \mathrm{Ci}, \sim 4$ pmol FEOBV). Groups of mice were sacrificed at 5,45 , and 240 min posttracer and brain regions were dissected and counted for radioactivity.

\section{Rat biodistribution for dosimetry}

Male and female Sprague Dawley (SD) rats weighing 215-275 g were injected with $50-120 \mu \mathrm{Ci}$ of (-)$\left[{ }^{18} \mathrm{~F}\right] \mathrm{FEOBV}$ via femoral vein while anesthetized with ether, and then allowed to recover and resume normal activity. Groups of animals were sacrificed by decapitation at 5, 15, 30, and 120 min following injection, and tissues and fluids were excised and counted for radi oactivity in an auto-gamma counter. The radioactivity remaining in the carcass after removal of samples was measured in a dose calibrator. Values were corrected for decay and calculated as described above for mouse experiments. Each data point in the rat biodistribution data represents the mean \pm standard deviation of at least four animal values, except for sex organs, for which $n=2-3$. Dosimetry data were calculated using the rat biodistribution data, foll owing the MIRD formalism (Loevinger and Berman, 1976). The percent administered dose per organ values were modified to reflect the different proportions of organ to total body mass in rat and man (Roedler, 1980). Residence times were obtained by integration under the organ time vs. activity curves, with the effective hal flife of $(-)-\left[{ }^{18} \mathrm{~F}\right] \mathrm{FEOBV}$ assumed to be equal to the physical halflife of ${ }^{18} \mathrm{~F}$ for times exceeding the last data point. Residence times were entered into the MIRDOSE 2 program (Watson et al., 1988) for the generation of absorbed doses to sel ected target organs per unit of admi nistered activity.

\section{Rodent brain and blood metabolite assays}

Groups of three female CD-1 mice (24-30 g), under ether anesthesia, were injected intravenously with $\sim 1$ $\mathrm{mCi}$ of $\left[{ }^{18} \mathrm{~F}\right] \mathrm{FE} O B V$. They were allowed to recover and resume normal activity until time of sacrifice at 30 and 90 min following tracer injection. The whole brains of the three animals were removed, pool ed together, and homogenized in an equal volume of $\mathrm{pH} 7.6 \mathrm{TRIS} / \mathrm{salt}$ buffer (120 mM NaCl, $50 \mathrm{mM}$ TRIS, $5 \mathrm{mM} \mathrm{KCl}, 2 \mathrm{mM}$ $\mathrm{CaCl}_{2}, 1 \mathrm{mM} \mathrm{MgCl}_{2}$ ). The supernatant extract was separated from sediment by low-speed centrifugation and collected. The sediment was then shaken with a 3 $\mathrm{mL}$ portion of ethanol, recentrifuged, and the extract combined with the first. This step was repeated. The combined extracts, which contained more than $97 \%$ of the original brain radioactivity, were concentrated to near dryness under reduced pressure, then $\mathrm{CH}_{3} \mathrm{CN}$ (6 $\mathrm{mL}$ ) was added and the resulting heterogeneous mixture was concentrated to a vol ume of $1 \mathrm{~mL}$. The solution was decanted from the precipitated fatty solids, and the fats were rinsed once with $1 \mathrm{~mL}$ of fresh $\mathrm{CH}_{3} \mathrm{CN}$. The combined final $\mathrm{CH}_{3} \mathrm{CN}$ solution (overall recovery $59 \%$ from brain) was assayed by thin layer chromatography (Analtech silica, 2:1:1:0.2 hexane: $\mathrm{CH}_{2} \mathrm{Cl}_{2}$ : $\mathrm{Et}_{2} \mathrm{O}: \mathrm{Et}_{3} \mathrm{~N}$; Bioscan TLC plate reader; $\operatorname{Rf}_{\mathrm{FEOBV}}=0.75$ ) and HPLC (column: 5 micron C-18 silica, mobile phase: $1.5 \mathrm{~mL} /$ min, 3:1:1 $\mathrm{CH}_{3} \mathrm{CN}$ : $\mathrm{MeOH}: 20 \mathrm{mM} \mathrm{KHPO}_{4}, \mathrm{pH}$ 6.7, serial UV $(220 \mathrm{~nm})$ and $\gamma$ radioactivity $\left(\mathrm{CaF}_{2}\right)$ flow detectors; $\mathrm{k}_{\text {FEOBV }}^{\prime}=3.25$ ).

The brain radioactivity from two female rats was examined separately in the same way $30 \mathrm{~min}$ following 2.3 and $4.3 \mathrm{mCi}$ (femoral vein) injections of FEOBV. The overall recovery in these cases were $70 \%$ and $66 \%$.

Two anesthetized female rats wereinjected in thetail vein with 6 and $8 \mathrm{mCi}$ of $(-)-\left[{ }^{18} \mathrm{~F}\right] \mathrm{FEOBV}$, respectively. Blood samples (0.1-0.3 mL) were withdrawn from a catheter in the vena cava at 5, 10, 30, and $60 \mathrm{~min}$ postinjection, diluted with $1 \mathrm{~mL}$ of isotonic saline, and centrifuged. In each sample the plasma was collected and $1 \mathrm{~mL}$ of $70 \%$ ethanol was added to the cells; the tube was vibramixed bri efly, centrifuged again, and the supernatant collected and combined with the plasma. The combined extract and residual solids from each blood sample were counted separately, and in cases where the extract recovery was less than $80 \%$, the solids were subjected to a second extraction procedure in which they were washed twice with $1 \mathrm{~mL}$ portions of $10 \%$ trifluoroacetic acid in methanol. All extracts were concentrated, made basic with triethylamine, and analyzed by TLC.

\section{In vivo rat brain autoradiography}

Two restrained conscious female SD rats were injected intravenously with (-)-[18F]FEOBV (4-9 mCi/ rat), and then $5 \mathrm{~min}$ and $3 \mathrm{~h}$ later they were sacrificed by intravenous pentobarbital, followed by $\mathrm{KCl}$ injection. Brains were quickly excised, frozen in powdered $\mathrm{CO}_{2}$ ice, coated with frozen section imbedding medium (Lipshaw, Detroit, $\mathrm{MI}$ ) and sectioned at $-15^{\circ} \mathrm{C}$ into $20-\mu \mathrm{m}$ thick slices. Brain slices were air-dried at $85^{\circ} \mathrm{C}$ on polylysine-treated slides and were exposed to LKB Betamax Ultrafilm for $12 \mathrm{~h}$ before development in Kodak D-19. Autoradiograms were analyzed by com- 
<smiles>CC(C)CC1CC(c2ccccc2)CCN1C1Cc2c(I)cccc2CC1O</smiles>

IBVM<smiles></smiles>

MABV
Fig. 1. Structures of 5-substituted benzovesamicol imaging agents IBVM, MABV, and FEOBV.

puter assisted densitometry (MCID System, I maging Research, St Catherines, ONT). Brain regions identified included areas with anticipated high and low levels of cholinergic markers on the basis of prior rodent and primate studies, and included the interpeduncular nucleus, basolateral amygdala, striatum, dentate gyrus, CA1 and CA3 fields of the hippocampus, frontal cortex, occi pital cortex, superficial layers of the superior colliculus, thalamus, and cerebellar cortex.

\section{RESULTS Rodent brain uptake}

$(-)-\left[{ }^{18} \mathrm{~F}\right] \mathrm{FEOBV}$ was rapidly taken up by the brain following intravenous injection. There was $2.68 \pm$ $0.62 \%$ of the injected dose present in the whole brain of mice at $5 \mathrm{~min}$, and nearly $1.5 \%$ remained in the brain at $6 \mathrm{~h}$. In rats the peak brain content was $1.58 \pm 0.20 \%$ of the administered dose at $15 \mathrm{~min}$. Mouse brain concentrations of $(-)-\left[{ }^{18} \mathrm{~F}\right] \mathrm{FEOBV}$ radioactivity were examined at 5, 10, and $45 \mathrm{~min}$, and 3, 4, 6, and $15 \mathrm{~h}$ following tracer administration. Time activity curves of [18F]FEOBV in selected brain regions are shown in Figure 2a. Tracer levels peaked within the first $5 \mathrm{~min}$ in all brain regions except striatum. Peak striatal accumulation in mice occurred between 45 and $180 \mathrm{~min}$. Clearance was slowest from striatum, fastest from cerebellum, and intermediate from other brain areas. Figure $2 \mathrm{~b}$ shows tissue [ ${ }^{18} \mathrm{~F}$ ]F E OBV localization in mice expressed as a ratio relative to cerebellar concentrations. The regional brain localization ratio in mice at $15 \mathrm{~h}$ postinjection, the latest time point examined, was 41:10:12:1 striatum: cortex: hippocampus: cerebellum, respectively. [ $\left.{ }^{18} \mathrm{~F}\right] \mathrm{FE}$ OBV mouse brain uptake and localization was very similar to that of the closely related analogs [ ${ }^{123 / 125}$ ] ] BVM (J ung et al., 1990) and [ $\left.{ }^{11} \mathrm{C}\right] \mathrm{MABV}$ (Kilbourn et al., 1990).

\section{In vivo rat brain autoradiography}

Rats sacrificed 5 min after tracer administration had fairly uniform $(-)-\left[{ }^{18} \mathrm{~F}\right] \mathrm{FEOBV}$ radioactivity levels throughout the brain, but $(-)-\left[{ }^{18} \mathrm{~F}\right] \mathrm{FEOBV}$ was distrib-<smiles>CCOCCOc1cccc2c1CC(N1CCC(c3ccccc3)CC1)C(O)C2</smiles>
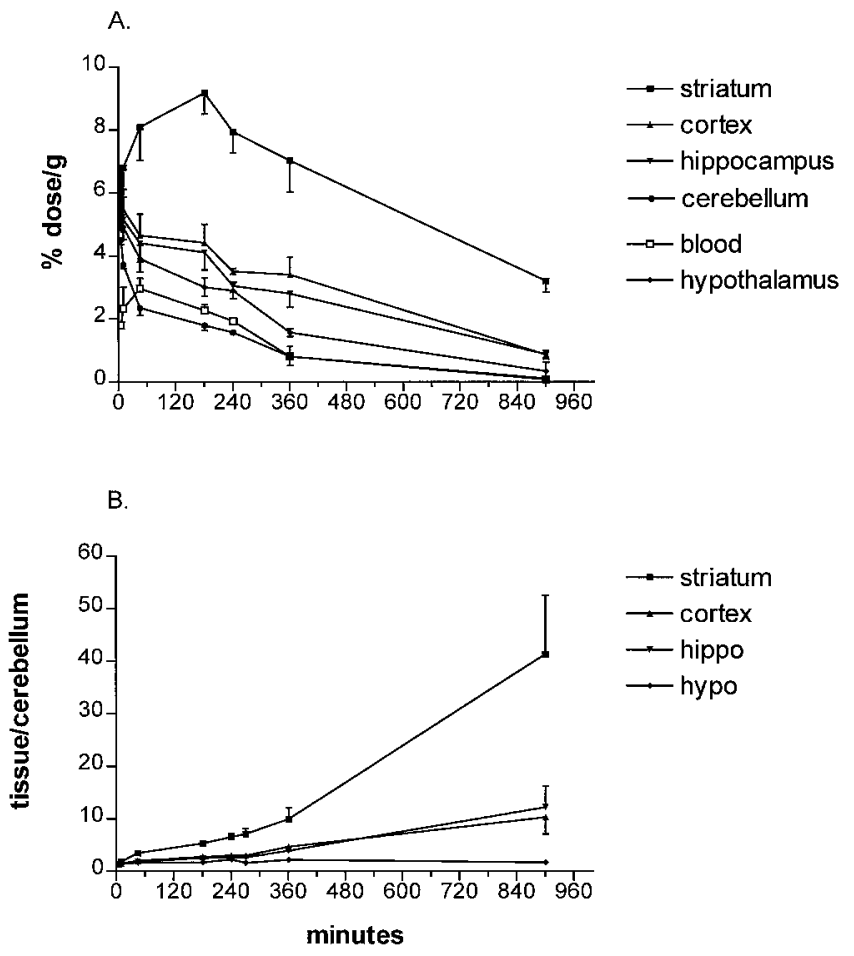

Fig. 2. (-)-FEOBV regional brain time activity curves (A), and tissue-to-cerebellum ratios (B), in the mouse. Values represent mean \pm SEM of at least three animals.

uted heterogenously in animals sacrificed at $3 \mathrm{~h}$, with high localizations in certain tissue areas. Highest radioactivity densities appeared in interpeduncular nucleus, followed by basolateral amygdala, striatum, dentate gyrus, CA1 field of the hippocampus, CA3 field of the hippocampus, frontal cortex, occipital cortex, superficial layers of the superior colliculus, thalamus, and cerebellar cortex. This rank order is consistent with the levels of ChAT (Fuhrmann et al., 1985; Tucek, 1988) and high affinity choline transport-hemicholinium-3 binding (Bekenstein and Wooten, 1989; Happe and Murrin, 1993; Vickroy et al., 1984). 
[18F]FEOBV: ACH SYNAPSE IMAGING AGENT FOR PET

TABLE I. Comparison of $\left[{ }^{18} \mathrm{~F}\right] \mathrm{FEOBV}$ relative brain concentrations in vivo with cholinergic markers in rodents

\begin{tabular}{|c|c|c|c|c|c|}
\hline Brain region & $\begin{array}{c}(-) \text {-FEOBV } \\
6 \mathrm{~h} \\
\mathrm{n}=3\end{array}$ & $\begin{array}{c}(-) \text {-FEOBV } \\
15 \mathrm{~h} \\
\mathrm{n}=3\end{array}$ & $\begin{array}{c}\text { ChAT activity* } \\
\text { ( } \mu \mathrm{mol} \text { ACh/g protein/h) }\end{array}$ & $\begin{array}{c}\text { AChE activity* } \\
\text { (mmol ACh/g protein/h) }\end{array}$ & $\begin{array}{c}{\left[{ }^{3} \mathrm{H}\right] \mathrm{Hemicholinium}} \\
\text { binding** } \\
\text { (fmol/mg protein) }\end{array}$ \\
\hline $\begin{array}{l}\text { Striatum } \\
\text { Cortex } \\
\text { Hippocampus } \\
\text { Hypothalamus } \\
\text { Cerebellum }\end{array}$ & $\begin{array}{c}9.96 \pm 4.21 \\
4.70 \pm 1.82 \\
3.91 \pm 1.51 \\
2.16 \pm 0.71\end{array}$ & $\begin{array}{c}41.3 \pm 19.5 \\
10.3 \pm 5.55 \\
12.2 \pm 7.03 \\
1.85 \pm 0.64 \\
1\end{array}$ & $\begin{array}{l}57.4 \pm 5.26 \\
13.9 \pm 1.50 \\
20.3 \pm 0.88 \\
9.14 \pm 0.86 \\
1.09 \pm 0.11\end{array}$ & $\begin{array}{c}23.2 \pm 1.31 \\
4.12 \pm 0.27 \\
5.52 \pm 0.23 \\
4.67 \pm 0.86 \\
\text { n.a. }\end{array}$ & $\begin{array}{c}165 \pm 9.3 \\
23.5 \pm 3.8 \\
46.5 \pm 4.3 \\
\text { n.a. } \\
4.8 \pm 0.8\end{array}$ \\
\hline
\end{tabular}

*Data from Fuhrmann, 1985.

**Data from Vickroy, 1984.

TABLE II. Effect of pretreatments

\begin{tabular}{|c|c|c|c|c|}
\hline & $\begin{array}{c}\text { Control } \\
(\mathrm{n}=5-10 / \text { interval }) \\
\text { mean } \pm \mathrm{SD}\end{array}$ & $\begin{array}{c}\text { Haloperidol } \\
(n=3 / \text { interval }) \\
\text { mean } \pm \text { SD }\end{array}$ & $\begin{array}{c}(+) \text { PPP } \\
(n=3 / \text { interval }) \\
\text { mean } \pm \text { SD }\end{array}$ & $\begin{array}{c}\text { E2020 } \\
(n=3 / \text { interval }) \\
\text { mean } \pm S D\end{array}$ \\
\hline \multicolumn{5}{|l|}{ \%dose/brain } \\
\hline $5 \mathrm{~min}$ & $2.68 \pm 0.62$ & $1.93 \pm 0.18(p 0.09)$ & $2.45 \pm 0.70$ & $2.90 \pm 0.18$ \\
\hline $45 \mathrm{~min}$ & $2.14 \pm 0.11$ & $1.55 \pm 0.06^{* * *}$ & $2.13 \pm 0.15$ & $1.93 \pm 0.20$ \\
\hline $240 \mathrm{~min}$ & $1.55 \pm 0.30$ & $1.50 \pm 0.11$ & $1.49 \pm 0.20$ & $1.42 \pm 0.12$ \\
\hline \multicolumn{5}{|c|}{ \%dose/g tissue } \\
\hline \multicolumn{5}{|c|}{ Striatum } \\
\hline $5 \mathrm{~min}$ & $6.02 \pm 0.75$ & $4.77 \pm 0.70(p 0.06)$ & $6.21 \pm 0.55$ & $6.14 \pm 1.0$ \\
\hline $45 \mathrm{~min}$ & $8.09 \pm 1.06$ & $8.67 \pm 0.90$ & $8.52 \pm 1.12$ & $7.63 \pm 0.49$ \\
\hline $240 \mathrm{~min}$ & $7.29 \pm 0.94$ & $9.88 \pm 0.54 * *$ & $7.50 \pm 0.74$ & $6.71 \pm 0.25$ \\
\hline \multicolumn{5}{|l|}{ Cortex } \\
\hline $5 \mathrm{~min}$ & $5.00 \pm 1.76$ & $4.56 \pm 0.22$ & $5.92 \pm 0.45$ & $5.82 \pm 0.52$ \\
\hline $45 \mathrm{~min}$ & $4.65 \pm 0.68$ & $4.11 \pm 0.07$ & $4.30 \pm 0.22$ & $4.10 \pm 0.29$ \\
\hline $240 \mathrm{~min}$ & $3.30 \pm 0.56$ & $3.46 \pm 0.40$ & $3.20 \pm 0.17$ & $2.85 \pm 0.05$ \\
\hline \multicolumn{5}{|c|}{ Hippocampus } \\
\hline $5 \mathrm{~min}$ & $5.12 \pm 0.30$ & $3.94 \pm 0.54 * *$ & $4.94 \pm 0.56$ & $5.19 \pm 0.28$ \\
\hline $45 \mathrm{~min}$ & $4.40 \pm 0.58$ & $3.92 \pm 0.08$ & $4.04 \pm 0.18$ & $3.73 \pm 0.41$ \\
\hline $240 \mathrm{~min}$ & $2.91 \pm 0.46$ & $3.22 \pm 0.15$ & $2.94 \pm 0.17$ & $2.70 \pm 0.30$ \\
\hline \multicolumn{5}{|l|}{ Cerebellum } \\
\hline $5 \min$ & $4.40 \pm 0.26$ & $3.30 \pm 0.28^{* *}$ & $4.28 \pm 0.28$ & $4.52 \pm 0.25$ \\
\hline $45 \mathrm{~min}$ & $2.34 \pm 0.24$ & $2.15 \pm 0.06$ & $2.48 \pm 0.04$ & $2.33 \pm 0.10$ \\
\hline $240 \mathrm{~min}$ & $1.19 \pm 0.37$ & $1.37 \pm 0.10$ & $1.46 \pm 0.21$ & $1.41 \pm 0.01$ \\
\hline \multicolumn{5}{|l|}{ Blood } \\
\hline $5 \mathrm{~min}$ & $2.11 \pm 0.28$ & $1.46 \pm 0.21 *$ & $2.03 \pm 0.13$ & $1.97 \pm 0.17$ \\
\hline $45 \mathrm{~min}$ & $2.96 \pm 0.33$ & $1.65 \pm 0.06 * * *$ & $3.16 \pm 0.14$ & $2.97 \pm 0.17$ \\
\hline $240 \mathrm{~min}$ & $1.42 \pm 0.59$ & $1.62 \pm 0.09$ & $1.94 \pm 0.09$ & $1.89 \pm 0.06$ \\
\hline \multicolumn{5}{|c|}{ Tissue/cerebellum ratios } \\
\hline \multicolumn{5}{|c|}{ Striatum } \\
\hline $45 \mathrm{~min}$ & $3.46 \pm 0.39$ & $4.04 \pm 0.52$ & $3.45 \pm 0.47$ & $3.02 \pm 0.40$ \\
\hline $240 \mathrm{~min}$ & $6.50 \pm 1.55$ & $7.26 \pm 0.80$ & $5.17 \pm 0.68$ & $4.76 \pm 0.13$ \\
\hline \multicolumn{5}{|l|}{ Cortex } \\
\hline 45 min & $1.99 \pm 0.30$ & $1.91 \pm 0.05$ & $1.72 \pm 0.10$ & $1.63 \pm 0.26$ \\
\hline $240 \mathrm{~min}$ & $2.99 \pm 0.87$ & $2.50 \pm 0.30$ & $2.23 \pm 0.30$ & $2.00 \pm 0.04$ \\
\hline
\end{tabular}

$* \mathrm{P}<.05,{ }^{* * \mathrm{P}}<.005, * * * \mathrm{P}<.0005$, different from controls by two-tailed t-test. Percent injected dose per gram of tissue, normalized to a $25 \mathrm{~g}$ mouse.

\section{In vivo cholinergic specificity and lack of interaction with dopamine neurons or sigma sites}

The tissue-to-cerebellum ratios of (-)-[18F $] \mathrm{FEOBV}$ in various brain regions of the mouse at 6 and $15 \mathrm{~h}$ postinjection showed close correspondence to the reported levels of ChAT and AChE and $\left[{ }^{3} \mathrm{H}\right.$ ]hemicholinium-3 binding in the same regions in rodents (Table I).

To investigate possible binding interactions of (-)$\left[{ }^{18} \mathrm{~F}\right] \mathrm{FEOBV}$ with dopamine $\mathrm{D}_{2}$ or $\sigma$ receptors, we examined the effects of large pretreatment doses of the potent $D_{2}$ and $\sigma$ ligand hal operidol, the $\sigma$ ligand $(+)-3-$ PPP (3-(3-hydroxyphenyl)-N-propylpiperidine, Koe et al., 1989), or E-2020 (donepezil, Aricept ${ }^{T R}$; a $\sigma$ ligand and AChE inhibitor, Brennan, 1997; Koe et al., 1991), on mouse brain distribution of the tracer. None of the pretreatments produced changes in the tissue/cerebel-
Ium ratios that were significantly different $(P<0.05)$ from 5, 45, or $240 \mathrm{~min}$ control values (Table II). Haloperidol pretreatment reduced thetotal $(-)-\left[{ }^{18} \mathrm{~F}\right] \mathrm{FE}-$ OBV brain uptake by $20-30 \%$, and blood activity by $25-50 \%$ at 5 min and 45 min following tracer administration. By $240 \mathrm{~min}$, total brain uptake and blood activity in the haloperidol group was the same as for controls, and striatal uptake of $(-)-\left[{ }^{18} \mathrm{~F}\right] \mathrm{FEOBV}$ was elevated $36 \%$ relative to controls. No significant differences from control data were seen in the (+)-PPP and E2020 groups' total brain uptake, regional brain uptake, or blood levels.

We examined the stereospecificity of $\left[{ }^{18} \mathrm{~F}\right] \mathrm{FEOBV}$ tissue uptake by labeling the (+)dextror otatory enantiomer, $(+)-\left[{ }^{18} \mathrm{~F}\right] \mathrm{FEOBV}$ and comparing its biodistribution in the mouse with $(-)-\left[{ }^{18} \mathrm{~F}\right] \mathrm{FEOBV}$ at 5,45 , and $180 \mathrm{~min}$. Both isomers showed fairly homogeneous 
brain uptakes of similar magnitude at $5 \mathrm{~min}$, but at later times the (+)-isomer brain distribution stayed uniform and comparable to the cerebellar level of $(-)-\left[{ }^{18} \mathrm{~F}\right] \mathrm{FEOBV}$, whereas the "cholinergic" pattern of brain localization was specific to the $(-)$-isomer of $\left[{ }^{18} \mathrm{~F}\right]$ FEOBV. The concentrations of $(-)-$ and $(+)-$ $\left[{ }^{18} \mathrm{~F}\right] \mathrm{FE}$ E OBV enantiomers at $180 \mathrm{~min}$ in selected tissues of the mouse are shown in Figure 4.

\section{Rat biodistribution, dosimetry, and metabolism}

As a prerequisite to using [18F]FEOBV in human studies, rat whole body biodistribution studies (Table III) were carried out to evaluate tracer disposition and cal culate expected radiation doses to man. [ $\left.{ }^{18} \mathrm{~F}\right] \mathrm{FEOBV}$ radioactivity was eliminated from the body mainly through the gastrointestinal tract. Nearly $50 \%$ of the injected dose was found in the small bowel and contents at $120 \mathrm{~min}$. The estimated human internal radiation dosimetry cal culated from rat biodistribution using the MIRD formalism is shown in Table IV. The upper large intestine was estimated to recei ve the largest dose, 0.67 $\mathrm{rad} / \mathrm{mCi}$. This calculation allows up to a $10 \mathrm{mCi}$ dose of $\left[{ }^{18} \mathrm{~F}\right] \mathrm{FE}$ OBV to be administered to humans.

Modest bone uptake of radioactivity was seen with $\left.{ }^{18} \mathrm{~F}\right] \mathrm{FEOBV}$ in rodents, which accumulated at a slow rate following injection. Bone uptake was most likely the result of metabolic defluorination of the tracer and deposition of inorganic ${ }^{18} \mathrm{~F}^{-}$. The inactive $(+)$isomer of $\left[{ }^{18} \mathrm{~F}\right] \mathrm{FE}$ EBV showed a similar level of bone uptake as the active (-) form (Fig. 4).

Rodent brain tissue was anal yzed for possi ble metabolites of $\left[{ }^{18} \mathrm{~F}\right] \mathrm{FEOBV}$ at two times following injection. The only radioactive species extractable from either mouse or rat brain 30 and 90 min after administration was unmetabol ized FEOBV. The recovery of radioactivity from brain homogenates by the initial buffer/ethanol extraction process was $90-97 \%$, but large amounts of lipid were present in theinitial extract which interfered with thin layer chromatography (TLC). The fatty substances were precipitated by addition of $\mathrm{CH}_{3} \mathrm{CN}$ and the final extract was then analyzed by TLC without difficulty. This defatting step reduced total recovery to $60-70 \%$, but no selective precipitation of FEOBV metabolites occurred with the fats. HPLC analysis of the fat precipitate resolubilized in $\mathrm{CH}_{2} \mathrm{Cl}_{2}$ found only authentic [ $\left.{ }^{18} \mathrm{~F}\right] \mathrm{FE}$ OBV present.

Radioactive metabolites of FEOBV appeared quickly in rodent blood, were highly polar in nature, and easily distinguishable from parent agent on TLC. They partitioned strongly with the blood cell solids and resisted extraction by the saline/ethanol combination, but the methanol/trifluoroacetic acid mixture sol ubilized them. When this extract was made basic with triethylamine or $\mathrm{KOH}$ and then analyzed by normal phase TLC, all radioactivity remained at the origin. Passage of the basified extract through a short alumina column and rinsing with methanol resulted in little trapping of radioactivity on the column. This suggested that the polar metabolite(s) was not inorganic [ $\left.{ }^{18} \mathrm{~F}\right]$ fluoride ion. Based on analyses from two rats, the percentage of unmetabolized FEOBV in whole blood was $\sim 80 \%$ at 5 $\mathrm{min}, 65-70 \%$ at $10 \mathrm{~min}, \sim 50 \%$ at $30 \mathrm{~min}$, and less than $10 \%$ at $60 \mathrm{~min}$. If the FE OBV blood metabolite profile in rats holds true for primates, it may be possible to do accurate blood activity metabolite corrections of the input function in FEOBV-PET studies without the need for chromatography, using a simple centrifugation of whole blood diluted with a saline alcohol extractant. In this case, the percentage of total blood activity in the decanted supernatant would be equal to the amount of unmetabolized FEOBV in the blood.

\section{Toxicity}

Unlabeled (-)-FEOBV was a strong neuromuscular blocking agent in rodents. Mice given parenteral doses quickly exhibited acutecurarelike symptoms characteristic of vesamicol intoxication (Rogers et al., 1989). Intravenous doses as low as $30 \mu \mathrm{g} / \mathrm{kg}(-)$-FEOBV were lethal within $30 \mathrm{~min}$. By contrast, (+)-FEOBV did not kill mice at doses up to $4,000 \mu \mathrm{g} / \mathrm{kg}$. Animals ventilated mechanically survived at least five times the mean lethal dose of (-)-FEOBV, suggesting that the primary lethal event was respiratory paralysis. Survivors recovered to apparent normalcy after 1-2 h, indicating (-)-FEOBV was el iminated or otherwise detoxified at a fairly rapid rate in rodents. No obvious behavioral or neurological signs of longer term neurotoxicity were seen in a small number of mice that were observed for 2 days following acute sublethal doses of (-)-FEOBV.

\section{DISCUSSION}

This work is a continuation of our earlier efforts to develop radioiodinated and carbon-11 labeled benzovesamicols [ ${ }^{123}$ ] ] BVM and [11 C]M ABV as VAChT imaging agents for studying chol inergic function in Alzheimer's disease (J ung et al., 1990; Kilbourn et al., 1990; Mulholland et al., 1991a; Mulholland and J ung, 1992). These agents have shown regional localization in vivo that closely matches the distributions of cholinergic markers such as ChAT, high affinity choline uptake, and acetylcholinesterase. The basic premise underlying the applicability of benzovesamicol radiotracers in studies of $A D$ is that VAChT levels change in parallel fashion and magnitude with other cholinergic marker proteins, in particular ChAT, over the course of the disease. The validity of this assumption has been debated, based on results of some early studies showing mismatches between $\left[{ }^{3} \mathrm{H}\right]$ vesamicol binding and ChAT in postmortem AD brains (Kish et al., 1990; Ruberg et al., 1990), but more recent studies using higher affinity VAChT ligands (Efange et al., 1995b) or immunocytochemical probes (Gilmor et al., 1997) suggest VAChT and ChAT may in fact track cl osely together in AD and chol inergic 


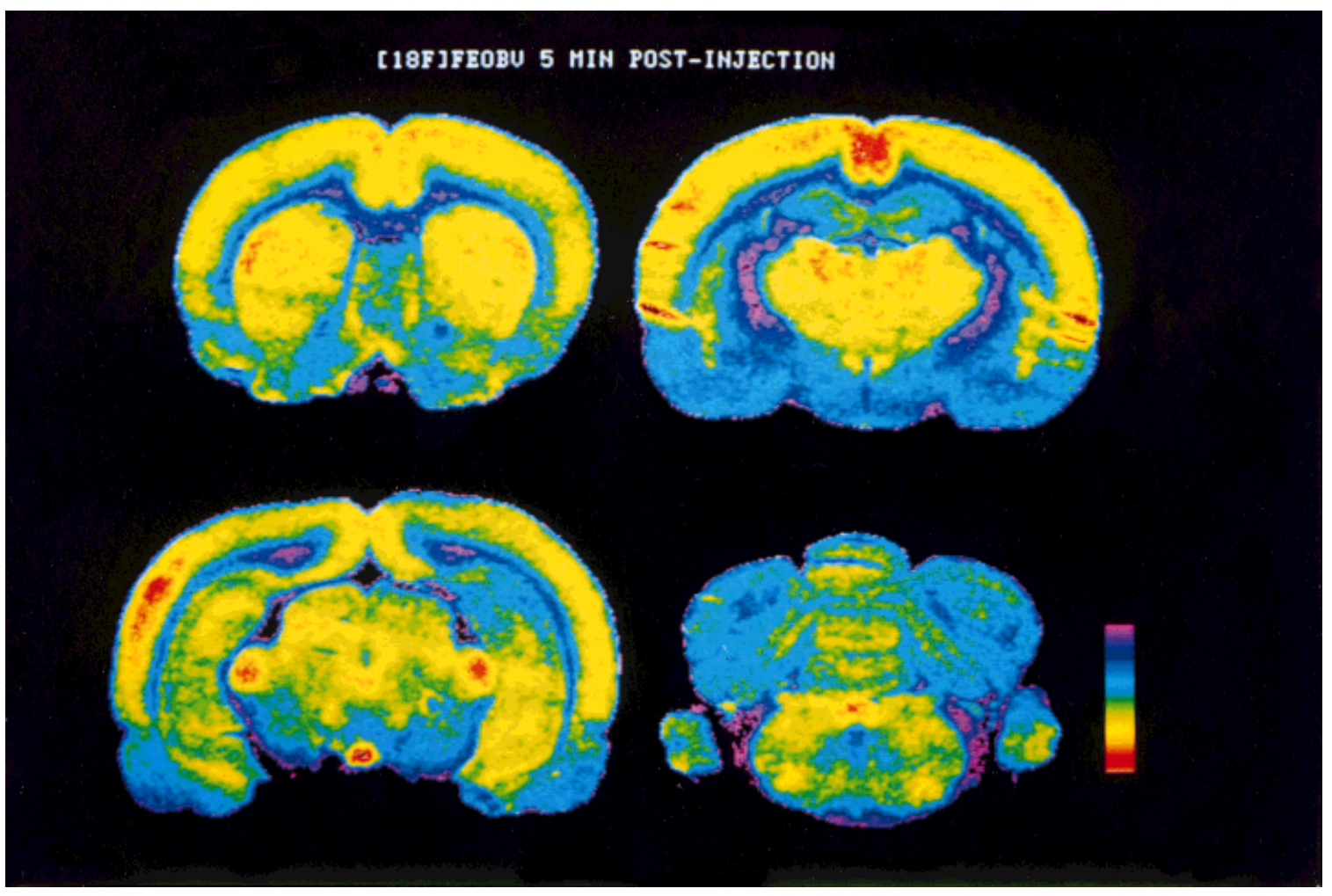

A

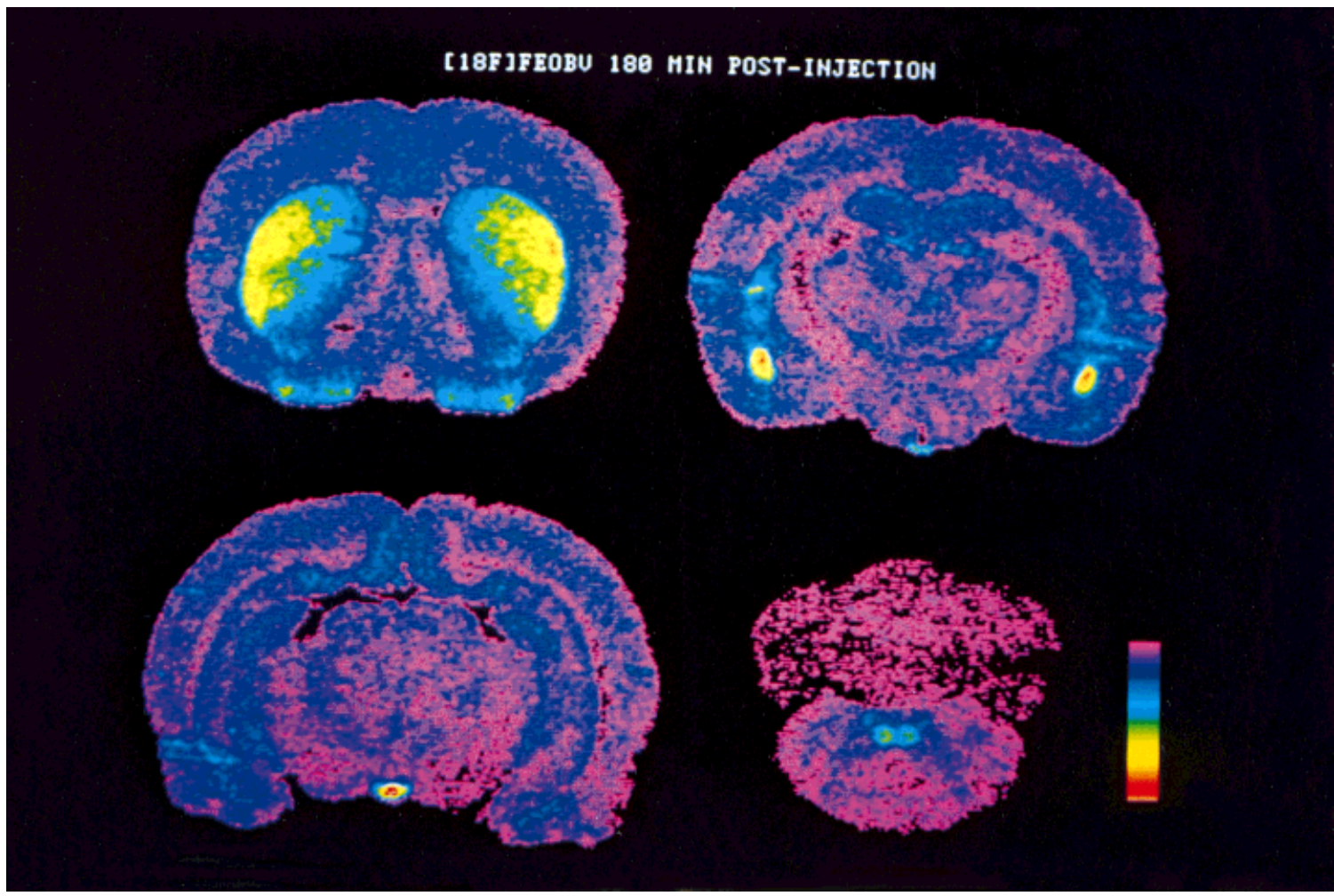

Fig. 3. Autoradiographic distribution of $(-) F E O B V$ in rat brain at $5 \mathrm{~min}$ (A) and $180 \mathrm{~min}$ (B) following bolus i.v. tracer injection. Each time panel shows coronal sections at comparable rostrocaudal levels from the head of the caudate (upper left) to the cerebellum and brain stem (lower right). Tracer concentration is indicated by pseudocolor transformation, according to the scale at the lower right of each panel, with red and violet representing the highest and lowest levels, respectively. Note the laminar cortical and selective subcortical retention is apparent even at $5 \mathrm{~min}$. At $180 \mathrm{~min}$, strong retention is present in caudate (upper left section), basolateral amygdala (upper right), interpeduncular nucleus (lower left), and hypoglossal nucleus (lower right). 


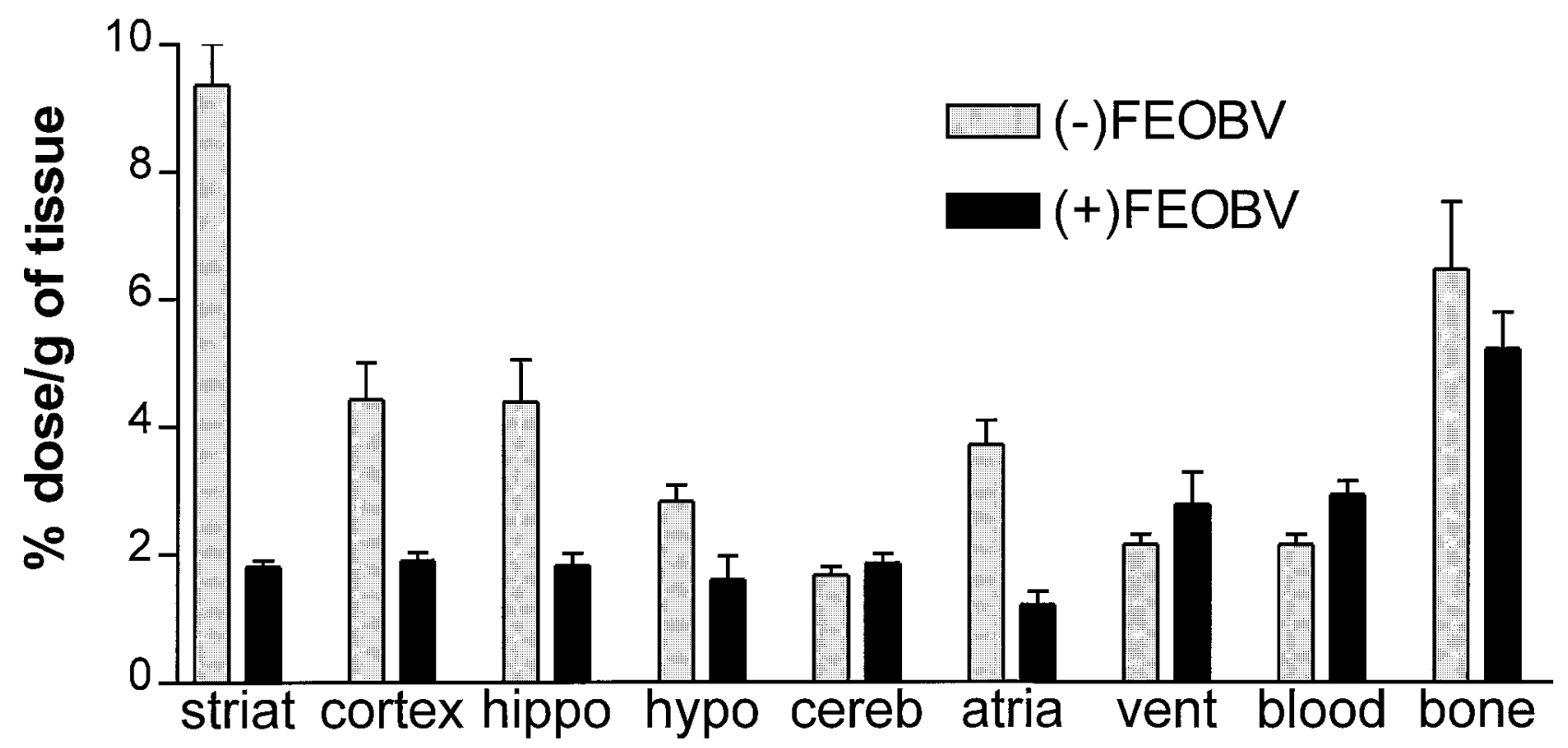

Fig. 4. Comparison of tissue uptakes of $(-)$ and $(+)$ isomers of $\left[{ }^{18} \mathrm{~F}\right] \mathrm{FEOBV}$ in the mouse at $180 \mathrm{~min}$. Values represent mean $\pm \mathrm{SD}$ of at least three animals.

TABLE III. Whole body biodistribution of FEOBV in rats

\begin{tabular}{|c|c|c|c|c|}
\hline & $5 \mathrm{~min}$ & $15 \mathrm{~min}$ & $30 \mathrm{~min}$ & $120 \mathrm{~min}$ \\
\hline Brain & $1.47 \pm 0.11$ & $1.58 \pm 0.20$ & $1.15 \pm 0.12$ & $0.87 \pm 0.13$ \\
\hline Eyeballs & $0.05 \pm 0.01$ & $0.05 \pm 0.00$ & $0.06 \pm 0.00$ & $0.09 \pm 0.01$ \\
\hline Heart & $0.77 \pm 0.09$ & $0.64 \pm 0.07$ & $0.46 \pm 0.02$ & $0.30 \pm 0.03$ \\
\hline Lung & $3.19 \pm 0.45$ & $2.12 \pm 0.47$ & $1.25 \pm 0.10$ & $0.53 \pm 0.14$ \\
\hline Liver & $11.58 \pm 0.89$ & $6.93 \pm 0.64$ & $6.38 \pm 0.81$ & $2.36 \pm 0.32$ \\
\hline Pancreas & $1.16 \pm 0.23$ & $2.01 \pm 0.16$ & $1.42 \pm 0.40$ & $0.40 \pm 0.06$ \\
\hline Spleen & $0.80 \pm 0.18$ & $0.73 \pm 0.11$ & $0.53 \pm 0.06$ & $0.18 \pm 0.04$ \\
\hline Adrenal & $0.18 \pm 0.06$ & $0.06 \pm 0.05$ & $0.06 \pm 0.02$ & $0.03 \pm 0.01$ \\
\hline Kidney & $3.39 \pm 0.40$ & $2.25 \pm 0.04$ & $1.53 \pm 0.15$ & $0.76 \pm 0.08$ \\
\hline Stomach & $1.11 \pm 0.13$ & $1.34 \pm 0.12$ & $1.23 \pm 0.26$ & $0.54 \pm 0.11$ \\
\hline Stomach contents & $0.28 \pm 0.12$ & $1.60 \pm 1.00$ & $3.43 \pm 2.31$ & $0.93 \pm 0.01$ \\
\hline Small intestine & $5.36 \pm 1.53$ & $6.50 \pm 1.44$ & $6.72 \pm 2.62$ & $5.81 \pm 1.84$ \\
\hline Small intestine contents & $1.80 \pm 0.69$ & $1.74 \pm 0.61$ & $2.26 \pm 0.81$ & $42.62 \pm 3.37$ \\
\hline Caecum & $0.51 \pm 0.10$ & $0.45 \pm 0.08$ & $0.42 \pm 0.10$ & $0.48 \pm 0.05$ \\
\hline Caecum contents & $0.54 \pm 0.21$ & $0.54 \pm 0.07$ & $1.21 \pm 0.29$ & $2.15 \pm 1.15$ \\
\hline Large intestine & $0.98 \pm 0.26$ & $0.89 \pm 0.16$ & $0.81 \pm 0.11$ & $0.70 \pm 0.12$ \\
\hline Large intestine contents & $0.28 \pm 0.09$ & $0.18 \pm 0.10$ & $0.65 \pm 0.29$ & $0.54 \pm 0.24$ \\
\hline Ovary & $0.28 \pm 0.01$ & $0.14 \pm 0.01$ & $0.11 \pm 0.01$ & $0.05 \pm 0.01$ \\
\hline Muscle* & $0.32 \pm 0.14$ & $0.30 \pm 0.04$ & $0.27 \pm 0.05$ & $0.18 \pm 0.02$ \\
\hline Bone* & $0.32 \pm 0.01$ & $0.42 \pm 0.06$ & $0.30 \pm 0.01$ & $0.33 \pm 0.06$ \\
\hline Urine & $0.07 \pm 0.01$ & $0.23 \pm 0.05$ & $1.05 \pm 0.36$ & $2.72 \pm 0.12$ \\
\hline Blood* & $0.22 \pm 0.03$ & $0.22 \pm 0.03$ & $0.026 \pm 0.03$ & $0.28 \pm 0.02$ \\
\hline Testes & $0.71 \pm 0.03$ & $0.75 \pm 0.02$ & $0.98 \pm 0.03$ & $0.82 \pm 0.12$ \\
\hline Rest of carcass & $68.2 \pm 2.2$ & $67.7 \pm 1.8$ & $68.9 \pm 3.6$ & $37.67 \pm 3.1$ \\
\hline Total recovery & $101 \pm 2.5$ & $98 \pm 1.9$ & $98.4 \pm 3.0$ & $95 \pm 4.0$ \\
\hline
\end{tabular}

Values are the mean percent injected dose per organ \pm SD of at least four animals at each time point, except where noted otherwise.

*Values expressed as percent injected dose per gram.

lesion models. It can be argued that vesamicol itself is not a particularly good ligand for VAChT, since it also binds other receptors (see below), and its affinity for VAChT, $\left(\mathrm{K}_{\mathrm{d}} \sim 11-36 \mathrm{nM}\right.$ ratbrain, Marien et al., 1987); 1 $\mathrm{nM}_{\text {torpedoorgan, }}$ Rogers et al., 1993a) is much weaker than analogs such as aminobenzovesamicol, ABV $\left(\mathrm{K}_{d}=6.5\right.$ pM, Rogers et al., 1993a). IBVM, MABV, and FEOBV are very close analogs of $A B V$ and have similar affinities as ABV for the VAChT, as indicated by the similar $I C_{50}$ values for inhibition of ${ }^{3} \mathrm{H}-\mathrm{MABV}$ binding to rodent cortical membranes ( ung et al., 1996; Mulholland, unpublished).

Although it is very similar to $\left[{ }^{123} \mid\right] \mid B V M$ and $\left.{ }^{11} \mathrm{C}\right] \mathrm{MABV}$ in VAChT binding properties in vivo, $\left.{ }^{1}{ }^{18} \mathrm{~F}\right] \mathrm{FEOBV}$ may possess advantages over the other two agents as an imaging tracer for AD. When used with PET, [ $\left.{ }^{18} \mathrm{~F}\right] \mathrm{FE} O B V$ has intrinsic quantification and resolution advantages over [ ${ }^{123}$ ] ] BVM/SPECT, which could result in improved sensitivity and precision in measuring cortical and hippocampal VAChT losses in 
TABLE IV. FEOBV doseestimates

\begin{tabular}{lcc}
\hline Target organ & $\begin{array}{c}\text { Total dose } \\
\text { rad/mCl }\end{array}$ & $\begin{array}{c}\text { Rad } \\
\text { dose/10 } \\
\mathrm{mCi}\end{array}$ \\
\hline Brain & 0.026 & 0.26 \\
Lungs & 0.04 & 0.4 \\
Heart & 0.05 & 0.5 \\
Bone marrow & 0.064 & 0.64 \\
Spleen & 0.072 & 0.72 \\
Liver & 0.086 & 0.86 \\
Adrenal & 0.09 & 0.9 \\
Uterus & 0.11 & 1.1 \\
Lower large intestine & 0.2 & 2 \\
Pancreas & 0.2 & 2.7 \\
Ovaries & 0.27 & 3.9 \\
Testes & 0.39 & 6 \\
Small intestine & 0.6 & 6.7 \\
Upper large intestine & 0.67 & 0.6 \\
Whole body & 0.06 & \\
\hline
\end{tabular}

AD (Kuhl et al., 1996). While [11 C]MABV is also a PET agent, $\left[{ }^{18} \mathrm{~F}\right] \mathrm{FEOBV}$ benefits from a longer halflife, which enables late imaging at a point where near steady-state binding levels are reached. Also, because of differences in labeling chemistries between ${ }^{18} \mathrm{~F}$ and ${ }^{11} \mathrm{C}$, [ $\left.{ }^{18} \mathrm{~F}\right] \mathrm{FEOBV}$ can be obtained routinely at much higher specific activity and lower dose masses than $\left[{ }^{11} \mathrm{C}\right] \mathrm{MABV}$, thus improving the safety factor of $\left[{ }^{18} \mathrm{~F}\right] \mathrm{FE} O \mathrm{OBV}$ in imaging studies.

A number of ${ }^{18} \mathrm{~F}$-labeled benzovesamicols and vesamicols have been evaluated in the past as cholinergic neuron imaging agents (Fig. 5). Our earlier work with fluorobenzylamino-benzovesamicol (FBnABV) showed the compound to have favorable cholinergic regional brain distribution patterns in rodents and primates following i.v. injection, but it suffered from relatively low brain extraction, possibly due to the compound's high lipophilicity (Mulholland et al., 1991a,b). Two $\left[{ }^{18} \mathrm{~F}\right]$ fluoroacetyl derivatives of aminobenzovesamicol called NEFA and FAA al so have been reported (I ngvar et al., 1993; Rogers et al., 1993b). FAA underwent rapid metabolic loss of the label, but the more stable analog NEFA showed a cholinergic pattern of regional brain localization, and its binding was stereoselective to the (-) isomer (Ingvar et al., 1993). In addition, two fluorinated vesamicols have been studied. [ $\left.{ }^{18} \mathrm{~F}\right] \mathrm{F}$ luoromethylvesamicol had very high brain extraction but did not distribute in a pattern consistent with cholinergic innervation (Rogers et al., 1993b). Another agent called $\left[{ }^{18} \mathrm{~F}\right.$ ]fluorobenzyltrozamicol (FBT) showed good brain uptake and moderate cholinergic localization, with a striatum/cerebellum ratio $\sim 2$ at $3 \mathrm{~h}$ in rodents as well as primates (Efange et al., 1994; Mach et al., 1997).

Several vesamicol tracers have been reported to interact with additional binding sites and neurotransmitter systems besides the VAChT. Vesamicol itself binds to $\sigma$ receptors and a "vesamicol-binding-protein," independent of the VAChT (Hicks et al., 1991). Possibly because of these secondary interactions, biodistribution studies using tritiated (-)-vesamicol showed poor in vivo localization in cholinergic brain areas (J ung et al., 1990). Some vesamicol analogs (Efange et al., 1995a) and (+)-benzovesamicol isomers (J ung et al., 1996) also show high affinity for $\sigma$ receptors. Furthermore, dramatic increases in striatal tracer binding, up to $200 \%$ in some cases, have been reported with certain analogs following acute treatment with dopamine receptor antagonists (Ingvar et al., 1993; Efange et al., 1994, 1995a, 1996). These other interactions could complicate the interpretation of tracer data intended to assess cholinergic presynaptic function.

We were unable to find evidence of strong binding interactions in vivo of $(-)-\left[{ }^{18} \mathrm{~F}\right] \mathrm{FE} O \mathrm{OBV}$ with noncholinergic receptors. Pharmacological pretreatment of mice with large doses of the $\sigma$ ligand (+)-3-PPP, or E-2020, a potent acetylcholinesterase inhibitor which also binds $\sigma$ receptors, did not significantly alter the brain uptake or regional localization of $(-)-\left[{ }^{18} \mathrm{~F}\right] \mathrm{FEOBV}$ (Table II). Reductions in $(-)-\left[{ }^{18} \mathrm{~F}\right] \mathrm{FE}$ OBV total brain uptake and blood levels occurred following haloperidol, a potent antagonist of both $D_{2}$ and $\sigma$ receptors, but it is likely that blood flow changes caused by the near-stupefying haloperidol doses given were responsible for the alterations. In the 240-min haloperidol group, but not in the earlier treatment groups, we did observe a striatal \%dose/g increase relative to controls that was significant, and a nonsignificant trend $(P>0.05)$ toward increased \%dose/g levels for cortex, hippocampus and cerebellum. However, the relative brain (-)$\left[{ }^{18} \mathrm{~F}\right] \mathrm{FE}$ OBV concentrations of the haloperidol groups, expressed as an average of tissue-to-cerebellum ratios from each animal, did not differ from controls (Table II). This suggests, further, that haloperidol pretreatment altered hemodynamic factors controlling tracer delivery to the brain, and did not modulatereceptor availability at the cellular level.

Our results argue that $\mathrm{FEOBV}$ is not interacting competitively at sigma or $\mathrm{D}_{2}$-like receptor sites. In vitro, we found haloperidol to be a very weak inhibitor $\left(\mathrm{IC}_{50}>1 \mu \mathrm{M}\right)$ of benzovesamicol $\left[{ }^{3} \mathrm{H}\right] \mathrm{MABV}$ binding to mouse striatal and cortical membranes (Mulholland, unpublished findings). Furthermore, the equivocal effects of haloperidol on striatal $(-)-\left[{ }^{18} \mathrm{~F}\right] \mathrm{FEOBV}$ binding we observed in mice indicate that acute $D_{2}$ receptor antagonism did not modulate (increase) (-)-[18F]FEOBV binding to the VAChT through a mechanism involving blockade of normal dopamine inhibitory input onto cholinergic interneurons in the striatum. There is evidence for an inhibitory feedback circuit in the striatum and substantia nigra involving dopamine $D_{2}$, acetylcholine, and GABA neurons (Lehmann and Langer, 1983), and several investigators have suggested this interneuronal mechanism to explain rapid, large increases they have observed in in vivo striatal binding of certain vesamicol tracers fol lowing acute $D_{2}$ antagonist pretreatments (Efange et al., 1994; I ngvar et al., 1993). We used haloperidol pretreat- 
<smiles>CC(C)CC1CCN(C2Cc3c(cccc3NCc3ccc(F)cc3)CC2O)CC1</smiles>

FBnABV

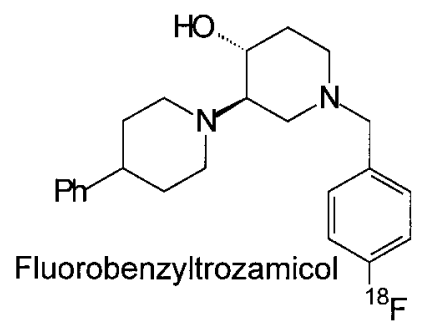<smiles>[R]C(=O)Nc1cccc2c1CC(N1CCC(c3ccccc3)CC1)C(O)C2</smiles>

NEFA; $\mathrm{R}=\mathrm{C}_{2} \mathrm{H}_{5}$ FAA; $\quad \mathrm{R}=\mathrm{H}$<smiles>OC1CCC(C[18F])CC1N1CCC(c2ccccc2)CC1</smiles>

Fluoromethylvesamicol
Fig. 5. Various fluorine-18 vesamicol analogs studied as cholinergic terminal imaging agents. ment doses 10-30 times higher than those investigators employed, but saw little effect on $(-)-\left[{ }^{18} \mathrm{~F}\right]$ FEOBV striatal localization. It should be pointed out we used different species and intervals between haloperidol pretreatment and tracer injection in our study. Further investigation may be necessary to resolve whether our differing results are due to altered experimental conditions or basic differences in tracer properties between FEOBV and other vesamicol agents.

$(-)-\left[{ }^{18} \mathrm{~F}\right] \mathrm{F} E \mathrm{EOBV}$ was excreted primarily through the gastrointestinal tract. This excretion pattern results in the large bowel being the body tissue which receives the highest radioactive burden from intravenously administered $(-)-\left[{ }^{18} \mathrm{~F}\right] \mathrm{FEOBV}$, and limits the al lowable dose to $10 \mathrm{mCi} /$ year in adult humans, based on estimated dosimetry calculations from rat data (TableIV). Gastrointestinal excretion is also the major disposition pathway of $\left[{ }^{123} \mid\right]$ lBVM in rats and humans (Kuhl et al., 1994).

The absence of labeled brain metabolites of FEOBV in rodents is a desirable feature of this agent. Assuming this holds true in primates, it greatly simplifies the tasks of estimating tracer brain transport and VAChT binding site densities from PET studies with (-)$\left[{ }^{18} \mathrm{~F}\right] \mathrm{FE}$ EBV, since the total brain signal is contributed by a single radiochemical entity. Furthermore, the simple blood metabolism of $(-)-\left[{ }^{18} \mathrm{~F}\right] \mathrm{FE} O B V$ makes it easy to do metabolite corrections of the plasma input function for quantitative imaging studies. The resistance of FEOBV to metabolic defluorination and bone deposition is also noteworthy. In general, $\left.{ }^{18} \mathrm{~F}\right]$ fluoroal$\mathrm{kyl}$ and $\left[{ }^{18} \mathrm{~F}\right]$ fluoroalkylamino groups tend to be more prone to loss of inorganic ${ }^{18} \mathrm{~F}-$ than are $\left[{ }^{18} \mathrm{~F}\right]$ fluoroaromatic groups. However FEOBV has a [ $\left.{ }^{18} \mathrm{~F}\right]$ fluoroethoxy group, and the presence of a vicinal oxygen atom in this group appears to stabilize the ${ }^{18} \mathrm{~F}$-label against defluorination similar to the level of a $\left[{ }^{18} \mathrm{~F}\right]$ fluoroaromatic moi ety. Rel atively few $\left[{ }^{18} \mathrm{~F}\right.$ ]fluoroethyl ethers have been examined; however, in one case it was found this group conferred the greatest metabolic stability in a series of ${ }^{18} \mathrm{~F}$-label ed estrogens (French et al., 1993).

In vivo blocking studies using unlabeled vesamicol anal ogs to prevent or displace $(-)-\left[{ }^{18} \mathrm{~F}\right] \mathrm{FE} \mathrm{OBV}$ uptake were not feasible because of their high toxicity. Previous in vivo [123! ] BVM blocking attempts using vesamicol as the blocking treatment in rodents resulted in death at a vesamicol dose that blocked about $50 \%$ of control striatal IBVM uptake (J ung et al., 1990). However, in vitro ligand binding studies from this laboratory (Mulholland, unpublished findings) have found 5-substituted benzovesamicols to be very specific and saturable in their binding to striatal, cortical, or hippocampal membranes, and this binding was inhibited by nanomol ar to subnanomolar concentrations of structurally related benzovesami cols. For example, (-)-FEOBV inhibited specific binding of the probe (-)-5-[3 $\left.{ }^{3} \mathrm{H}\right]$ methylaminobenzovesamicol $\left(\left[{ }^{3} \mathrm{H}\right] \mathrm{MABV}, 80 \mathrm{Ci} / \mathrm{mmol}, 0.5 \mathrm{nM}\right.$ incubation concentration) to mouse cortical membranes with an apparent I $\mathrm{C}_{50}$ of $0.4 \mathrm{nM}$.

Biological stereospecificity is characteristic of other benzovesamicols and vesamicol itself. Both the toxicity and the cholinergic specificity were attributable al most exclusively to the (-)-(2R,3R)-isomer of FEOBV. Mice survived comparatively large doses of the (+)-isomer, $4,000 \mu \mathrm{g} / \mathrm{kg}$ i.v., that were 133 times greater than the mean lethal dose of the (-)-isomer. The rodent biodistributions of the two enantiomers were very different. $(+)-\left[{ }^{18} \mathrm{~F}\right] \mathrm{FEOBV}$ activity was uniform throughout the brain, and levels in all regions except cerebellum were lower than uptake of the (-)-isomer. (+)-[18F $]$ FEOBV did not accumulate in peripheral tissues rich in chol inergic terminals, such as atria, stomach, and pancreas, in which (-)-[18F ]FEOBV did localize (Fig. 4). Another indication of the biological stereospecificity of FEOBV was that the I $\mathrm{C}_{50}$ of (+)-FEOBV for inhibition of in vitro $(-)-\left[{ }^{3} \mathrm{H}\right] M A B V$ binding to cortical membranes was 
nearly three orders of magnitude higher than that of the (-)-isomer. The clear relation between toxicity and cholinergic localization in FEOBV enantiomers suggests strongly that vesicular ACh uptake inhibition is the direct cause of toxicity seen with (-)-FEOBV.

Toxic levels of vesamicol analogs cause respiratory paralysis, probably through nondepolarizing blockade of peripheral cholinergic neurotransmission. Nearly all of the benzovesamicols we studied with high chol inergic Iocal ization, including IBVM, MABV, and other analogs (Mulholland et al., 1991b), share similar levels of toxicity. Since binding and inhibition of VAChT at the picomolar level (Rogers et al., 1993a) appears to be a common mechanism underlying both the high cholinergic localization and toxicity of these agents, it is unlikely these two properties can be separated in the benzovesamicol class of cholinergic tracers.

High toxicity does not necessarily preclude usefulness as an imaging agent. Other very toxic compounds, including thallium-201, carfentanil, (Dannals et al., 1985), I BVM and epibatidineanal ogs (Ding et al., 1996; Horti et al., 1997; Musachio et al., 1997; Villemagne et al., 1997), have been used safely and/or are being developed currently as human PET and SPECT imaging agents. The very high specific activities attainable routinely in fluorine-18-labeled agents, and the sensitive HPLC techniques used universally in tracer purification and analysis, make production of safe imaging doses of $(-)-\left[{ }^{18} \mathrm{~F}\right] \mathrm{FEOBV}$ a reasonably straightforward process. For example, a $10 \mathrm{mCi}$ dose of $(-)-\left[{ }^{18} \mathrm{~F}\right] \mathrm{FEOBV}$ with specific activity of $5 \mathrm{Ci} / \mu \mathrm{mol}$, an easily achievable value in our experience, contains only $2 \mathrm{nmol}$ or $0.75 \mu \mathrm{g}$ of ( - )-FEOBV drug. This low mass quantity is less than $1 / 1,000$ of the estimated human toxic dose based on mouse data, 1-2 mg (2.7-5.42 $\mu \mathrm{mol}$, which incidentally is more than the total amount of labeling precursor we use per synthesis of $\left.(-)-\left[{ }^{18} \mathrm{~F}\right] \mathrm{FEOBV}\right)$, and provides a large margin of safety for human imaging studies. Nevertheless, it is important to recognize the potential risks of FEOBV and the vesamicol class in general, and practice care in the production and quality control standards for these tracers.

In conclusion, this work in rodents demonstrates $(-)-\left[{ }^{18} \mathrm{~F}\right] \mathrm{F}$ EOBV to be a promising radiotracer for mapping cholinergic synapses in vivo. It has high brain extraction, favorable metabolism, a strong cholinergic pattern of localization which correlates highly with brain chol ine acetyltransferase distribution, and lack of demonstrable extra-cholinergic binding interactions. Both the cholinergic tracer behavior and the pharmacological effects are stereospecific to the (-)-enantiomer. Further work is needed to evaluate regional brain kinetics of $(-)-\left[{ }^{18} \mathrm{~F}\right] \mathrm{FEOBV}$ in primates and develop imaging and analysis protocols to extract information from FEOBV-PET scans. It will then be possible to determine the utility of this new agent for measuring cholinergic synapse density and function in man using PET.

\section{ACKNOWLEDGMENTS}

The authors thank Dr. Yong-Woon J ung for providing intermediate compounds, Dr. David Gildersleeve for efforts in isolation and analysis of FEOBV enantiomers, Dr. Sunil Mukhopadhyay for assistance with autoradiography, and Katherine Carlson and Gerald Dreesen for assistance in metabol ite studies.

\section{REFERENCES}

Altar, C.A., and Marien, M.R. (1988) -[33 H Vesamicol binding in brain: Autoradiographic distribution, pharmacology, and effects of cholinergic lesions. Synapse, 2:486-493.

Bekenstein, J.W., and Wooten, G.F. (1989) Hemicholinium-3 binding sites in rat brain: A quantitative autoradiographic study. Brain Res., 481:97-105.

Brennan, M.B. (1997) Bringing back the memories. Chem. Eng. News, 75:29-32.

Dannals, R.F., Ravert, H.T., Frost, J J ., Wilson, A.A., Burns, H.D., and Wagner, H.N. (1985) Radiosynthesis of an opiate binding radiotracer: [11C]carfentanil. Int. J. Appl. Radiat. Isot., 36:303-306.

Davies, C.A., Mann, D.M.A., Sumpter, P.W., and Yates, P.O. (1987) A quantitative morphometric analysis of the neuronal and synaptic content of the frontal and temporal cortex in patients with Alzheimer's disease. J. Neurol. Sci., 78:151-164.

Degrado, T.R., Mulholland, G.K., Wieland, D.M., and Schwaiger, M. (1994) Evaluation of $(-)$ [18F ]fluoroethoxybenzovesamicol as a new PET tracer of cholinergic neurons inthe heart. Nud Med Biol. 21:189-195.

DeKosky, S.T., and Scheff, S.W. (1990) Synaptic loss in frontal cortex biopsies in Alzheimer's disease: Correlation with cognitive severity. Ann. Neurol., 27:457-464.

Ding, Y.-S., Gatley, S.J ., Fowler, J .S., Volkow, N.D., Aggarrwal, D., Logan, J ., Dewey, S.L., Liang, F., Carrol, F.I ., and Kuhar, M.J . (1996) Mapping nicotinic acetylcholine receptors with PET. Synapse, 24: 403-407.

Efange, S.M.N., Dutta, A.K., Michelson, R.H., Kung, H.F., Thomas, J .R., Billings, J ., and Boudreau, R.J . (1992) Radioiodinated 2-hydroxy-3-(iodophenyl)-1-(4-phenyl piperidinyl)propane: Potential radiotracer for mapping central cholinergic innervation in vivo. Nucl. Med. Biol., 19:337-348.

Efange, S.M.N., Michaelson, R.H., Khare, A.B., and Thomas, J.R. (1993) Synthesis and tissue distribution of (m-[125] ]iodobenzyltrozamicol ([125I ]MIBT): Potential radioligand for mapping central cholinergic innervation. J. Med. Chem., 36:1754-1760.

Efange, S.M.N., Mach, R.H., Khare, A., Michelson, R.H., Nowak, P.A., and Evora, P.H. (1994) p-[18F]Fluorobenzyltrozamicol $\left(\left[{ }^{18} \mathrm{~F}\right] \mathrm{FBT}\right)$ : Molecular decomposition-reconstitution approach to vesamicol receptor radioligands for positron emission tomography. Appl. Radiat. I sot., 45:465-472.

Efange, S.M.N., Khare, A.B., and Langason, R.B. (1995a) Comparative tissue distribution of conformationally restricted radioiodinated vesamicol receptor ligands. Nucl. Med. Biol., 22:437-444.

Efange, S.M.N., Garland, E.M., Staley, J.K., Khare, A.B., and Mash, D.C. (1995b) (+)-[125] MIBT binding in human temporal cortex reveals hypofunction in Alzheimer's disease. J. Labelled Comp. Radiopharm., 37:376-377.

Efange, S.M.N., Langason, R.B., and Khare, A.B. (1996) Age related diminution of dopamine antagonist-stimulated vesamicol receptor binding. J . Nucl. Med., 37:1192-1197.

Erickson, J.D., Varoqui, H., Schafer, M.K.H., Modi, W., Dibler, M.F., Weihe, E., Rand, J ., Eiden, L.E., Bonner, T.I., and Usdin, T.B. (1994) Functional identification of a vesicular acetylcholine transporter and its expression from a "cholinergic" gene locus. J . Biol. Chem., 269:21929-21932.

Erickson, J .D., Weihe, E., Schafer, M.K.H., Neale, E., Williamson, L., Bonner, T.I., Cheng, J.H.T., and Eiden, L.E. (1996) The VAChT/ ChaT "chol inergic gene locus": N ew aspects of genetic and vesicular regulation of cholinergic function. Prog. Brain Res., 109:69-82.

French, A.N., Napolitano, E., VanBrocklin, H.F., Hanson, R.N., Welch, M.J ., and Katzenellenbogen, J.A. (1993) Synthesis, radiolabeling and tissue distribution of $11 \beta$-fluoroalkyl- and 11ß-fluoroalkoxysubstituted estrogens: Target tissue uptake selectivity and defluorination of a homologous series of fluorine-18-label ed estrogens. Nud. Med. Biol., 20:31-47.

Fuhrmann, G., Durkin, T., Thiriet, G., Kempf, E., and Ebel, A. (1985) Cholinergic neurotransmission in the central nervous system of the Snell dwarf mouse. J. Neurosci. Res., 13:417-430.

Gilmor, M.L., Nash, N.R., Roghani, A., Edwards, R.H., Yi, H., Hersh, 
S.M., and A.I., L. (1996) Expression of the putative vesicular acetylcholine transporter in rat brain and localization in cholinergic synaptic vesicles. J . Neurosci., 16:2179-2190.

Gilmor, M.J ., Counts, S.C., Wiley, R.G., and Levey, A.I. (1997) Coregulation of the vesicular acetylcholine transporter (VACHT) and choline acetyltransferase (CHAT) in septohippocampal pathway lesions. Soc. Neurosci. Abstr., 23:695.

Gomez-Isla, T., Hollister, R., West, H., et al. (1997) Neuronal loss correlates with but exceeds neurofibrillary tangles in Alzheimer's disease. Ann. Neurol., 41:17-24.

Happe, H.K., and Murrin, L.C. (1993) High affinity cholinetransporter sites: Use of $\left[{ }^{3} \mathrm{H}\right]$ hemicholinium-3 as a quantitative marker. J. Neurochem., 60:1191-1201.

Hicks, B.W., Rogers, G.A., and Parsons, S.M. (1991) Purification and characterization of nonvesicular vesamicol-binding protein from electric organ and demonstration of a related protein in mammalian brain. J . Neurochem., 57:509-519.

Horti, A., Scheffel, U., Stathis, M., Finley, P., Ravert, H.T., London, E.D., and Dannals, R.F. (1997) Fluorine-18 FPH for PET imaging of nicotinic acetylcholine receptors. J. Nucl. Med., 38:1260-1265.

Ingvar, M., Stone-Elander, S., Rogers, G.A., et al. (1993) Striatal acetylcholine interactions: PET studies of the vesamicol receptor. NeuroReport, 4:1311-1314.

I rie, T., Fukushi, K., Akimoto, Y., Tamagami, H., and Nozaki, T. (1994) Design and evaluation of radioactive acetylcholine analogs for mapping brain acetylcholinesterase (ACHE) in vivo. Nucl. Med. Biol., 21:801-808.

Itzhaki, R.F. (1994) Possible factors in the etiology of Alzheimers disease. Mol. Neurobiol., 9:1-13.

J ung, Y.-W., Van Dort, M.E., Gildersleeve, D.L., and Wieland, D.M. (1990) A radiotracer for mapping cholinergic neurons of the brain. J . Med. Chem., 33:2065-2068.

J ung, Y.-W., Frey, K.A., Mulholland, G.K., del Rosario, R., Sherman, P.S., Raffel, D.M., Van Dort, M.E., Kuhl, D.E., Gildersleeve, D.L., and Wieland, D.M. (1996) Vesamicol receptor mapping of brain cholinergic neurons with radioiodine-labeled positional isomers of benzovesamicol. J. Med. Chem., 39:3331-3342.

Kilbourn, M.R., J ung, Y.-W., Haka, M.S., Gildersleeve, D.L., Kuhl, D.E., and Wieland, D.M. (1990) Mouse brain distribution of a carbon-11 labeled vesamicol derivative: Presynaptic marker of cholinergic neurons. Life Sci., 47:1955-1963.

Kilbourn, M.R., Snyder, S.E., Sherman, P.S., and Kuhl, D.E. (1996) In vivo studies of acetylcholinesterase activity using a labeled substrate, $\mathrm{N}-\left[{ }^{11} \mathrm{C}\right]$ methyl piperdin-4-yl propionate $\left.\left({ }^{11} \mathrm{C}\right] \mathrm{PMP}\right)$. Synapse, 22:123-131.

Kish, S.J ., Distefano, L.M., Dozic, S., Robitaille, Y., Rajput, A., Deck, J.H.N., and Hornykiewcz, O. (1990) [3H]Vesamicol binding in human brain chol inergic deficiency disorders. Neurosci. Lett., 117:347352.

Koe, B.K., Burkhart, C.A., and Lebel, L.A. (1989) (+)-[3H]3-(3Hydroxyphenyl)- $\mathrm{N}$-(1-propyl)piperidine binding to $\mathrm{S}$ receptors in mouse brain in vivo. Eur. J. Pharmacol., 161:263-266.

Koe, B.K., Fox, C.B., and Lebel, L.A. (1991) Structural classes of compounds with potent affinity for brain sigma binding sites. Soc. Neurosci. Abstr., 17:332.

Kuhl, D.E., Koeppe, R.A., Fessler, J .A., Minoshima, S., Ackerman, R.J ., Carey, J .E., Gildersleeve, D.L., Frey, K.A., and Wieland, D.M. (1994) In vivo mapping of cholinergic neurons in the human brain using SPECT and IBVM. J . Nucl. Med., 35:405-410.

Kuhl, D.E., Minoshima, S., Fessler, J .A., Frey, K.A., Foster, N.L., Ficaro, E.P., Wieland, D.M., and Koeppe, R.A. (1996) In vivo mapping of cholinergic terminals in normal aging, Alzheimer's disease and Parkinson's disease. J. Ann. Neurol., 40:399-410.

Lehmann, J ., and Langer, S.Z. (1983) The striatal cholinergic interneuron: Synaptic target of dopamine terminals? J . Neurosci., 10:11051120.

Loevinger, R., and Berman, M. (1976) A Revised Scheme for Calculating Absorbed Dose from Biologically Distributed Radionuclides, Vol. 1, Revised. Society of Nuclear Medicine, New York.

Mach, R.H., Voytko, M.L., Ehrenkaufer, R.L.E., Nader, M.A., Tobin, J.R., Efange, S.M.N., Parsons, S.M., Gage, H.D., Smith, C.R., and Morton, T.E. (1997) I maging cholinergic terminals using the tracer $\left[{ }^{18} \mathrm{~F}\right](+)-4$-fluorobenzyltrozamicol: In vitro binding studies and positron emission tomography studies in non-human primates. Synapse, 25:368-380.

Marien, M.R., Parsons, S.M., and Altar, C.A. (1987) Quantitative autoradiography of brain binding sites for the vesicular acetylcholinetransport blocker 2-(4-phenyl piperidino)cyclohexanol (AH5183). Proc. Natl. Acad. Sci. USA, 84:876-880.

Masliah, E., Miller, A., and Terry, R.D. (1992a) The synaptic organization of the neocortex in Alzheimer's disease. Med. Hypotheses, 41:334-340.

Masliah, E., Ellisman, M., Carragher, B., Mallory, M., et al. (1992b)
Three dimensional analysis of the relationship between synaptic pathology and neuropil threads in Alzheimer's disease. J. Neuropath. Exp. Neurol., 51:404-414.

Mulholland, G.K., Buck, F., Sherman, P.S., et al. (1991a) 4-[18F ] fluorobenzyl-ABV: A new potential marker for central cholinergic presynaptic sites. J . Nucl. Med., 32:P994.

Mulholland, G.K., Sherman, P.S., Pisani, T.L., et al. (1991b) Effect of lipophilicity on brain uptake of label ed aminobenzovesamcols. Potential tracers for cholinergic neurons. J. Cereb. Blood. Flow Metab., 11:S622.

Mulholland, G.K., and J ung, Y.-W. (1992) Improved synthesis of $\left.{ }^{[11} \mathrm{C}\right]$ methylaminobenzovesamicol. J . Labelled Comp. Radiopharm. 31:253-259.

Mulholland, G.K. J ung, Y.-W., Wieland, D.M., Kilbourn, M.R., and Kuhl, D.E. (1993) Synthesis of [18F] fluoroethoxy-benzovesamicol, a radiotracer for cholinergic neurons. J . Labelled Comp. Radiopharm. 33:583-591.

Musachio, J .L., Villemagne, V.L., Scheffel, U., Stathis, M., Finley, P. Horti, A., London, E.D., and Dannals, R.F. (1997) [125/123] ]IPH: A radioiodinated analog of epibatidine for in vivo studies of nicotinic acetylchol ine receptors. Synapse, 26:392-399.

Pappata, S., Tavitian, B., Traykov, L., et al. (1996) In vivo imaging of human cerebral acetylcholinesterase. J . Neurochem. 67:876-879.

Parsons, S.M., and Rogers, G.A. (1993) In vivo diagnostics for Alzheimer's disease based on the acetylcholine transporter. Ann. Rep. Med. Chem., 28:247-255.

Perry, E.K., Court, M.A., Piggott, M.A., and Perry, M.A. (1994) Chol inergic component in dementia and normal aging, B.C. Huppert F.A., O'Connor D.W., eds. Cambridge University Press, Cambridge, UK

Roedler, H. (1980) Accuracy of internal dose calculations with special consideration of radiopharmaceuticals biokinetics. In Radiopharmaceutical Dosimetry Symposium. Oak Ridge National Laboratory: HHS-Publ (FDA), pp. 1-20.

Rogers, G.A., Parsons, S.M., Anderson, D.C., Nilsson, L.M., Bahr, B.A. Kornreich, W.D., Kaufman, R., J acobs, R.S., and Kirtman, B. (1989) Synthesis, in vitro acetyl choline-storage-blocking activities, and biological properties of derivatives and anaologues of trans-2-(4phenylpiperidino)cyclohexanol (vesamicol). J . Med. Chem., 32:1217.

Rogers, G.A., Kornreich, W.D., Hand, K., and Parsons, S.M. (1993a) Kinetic and equilibrium characterization of vesamicol receptor ligand complexes with picomolar dissociation constants. Mol. Pharmacol., 44:633-641.

Rogers, G.A., Stone-Elander, S., Ingvar, M., Eriksson, L., Parsons, S.M., and Widen, L. (1993b) ${ }^{18} \mathrm{~F}-\mathrm{L}$ abelled vesamicol derivatives: Synthesis and preliminary in vivo small animal positron emission tomography. Nucl. Med. Biol., 21:219-230.

Roghani, A., Feldman, J., Kohan, S.A., Shirzadi, A., Gundersen, C.B., Brecha, N., and Edwards, R.H. (1994) Molecular cloning of a putative vesicular transporter for acetylcholine. Proc. Natl. Acad. Sci. USA, 91:10620-10624.

Ruberg, M., Mayo, W., Brice, A., Duykaerts, C., Hauw, J J ., Simon, H., LeM oal, M., and Agid, Y. (1990) Choline acetyl transferase activity and vesamicol binding in the temporal cortex of patients with Alzheimer's disease, Parkinson's disease, and rats with basal forebrain lesions. Neuroscience, 35:327-333.

Samuel, W., Terry, R.D., DeTeresa, R., et al. (1994) Clinical correlates of cortical and nucleus basalis pathology in Alzheimer's dementia. Arch. Neurol., 51:772-778.

Scheff, S.W., DeK osky, S.T., and Price, D.A. (1990) Quantitative assessment of cortical synaptic density in Alzheimer's disease. Neurobiol. Aging, 11:29-37.

Svennerholm, L., and Gottfries, C.-G. (1994) Membrane lipids, selectively diminished in Alzheimer's brains, suggest synapse loss as a primary event in early-onset form (type 1) and demyelination in late-onset form (typelI). J . Neurochem., 62:1039-1047.

Terry, R.D., Masliah, E., Salmon, D.P., Butters, N., DeTeresa, R., Hill, R., Hansen, L.A., and Katzman, R. (1991) Physical basis of cognitive alterations in Alzheimer's disease: Synaptic loss is the major correlate of cognitive impairment. Ann. Neurol., 30:572-580.

Tucek, S. (1988) Choline acetyltransferase and the synthesis of acetylcholine. In: Handbook of Experimental Pharmacology. V.P. Whittaker, ed. Springer Verlag, Berlin, pp. 125-165.

Vickroy, T.W., Roeske, W.R., and Yamamura, H.I. (1984) Sodium dependent high-affinity binding of ${ }^{3} \mathrm{H}$ ]hemicholinium-3 in the rat brain: A potentially selective marker for presynaptic cholinergic sites. Life Sci. 35:2235-2243.

Villemagne, V.L., Horti, A., Scheffel, U., Ravert, H.T., Finley, P. London, E.D., Wagner, H.N., and Dannals, R.F. (1997) Imaging nicotinic acetylcholine receptors with fluorine-18-FPH, an epibatidine analog. J. Nucl. Med., 38:1737-1741.

Watson, E., Stabin, M., and Bolch, W. (1988) MIRDOSE2, Oak Ridge Associated Universities, Oak Ridge, TN. 